\title{
Being Able to Stay or Learning to Stay: a Study of Rural Boys' Educational Orientations and Transitions
}

\author{
Anna-Maria Stenseth ${ }^{1}$ (D) - Unn-Doris K. Bæck ${ }^{2}$
}

Received: 4 November 2020 /Revised: 31 March 2021 / Accepted: 2 April 2021 / Published online: 26 April 2021

(C) The Author(s) 2021

\begin{abstract}
This study explores the influence of geographical location on young pupils' educational orientations and their transition from lower to upper secondary school; it pays particular attention to the voices of male youths from a rural area. More specifically, it investigates the interplay between gender and geographical contexts and the significance of these factors in understanding the processes associated with educational orientations. Margaret Archer's framework is used to analyse how pupils' agency is constrained and/ or enabled by objective structures. The data material consists of qualitative interviews with 18 pupils transitioning from lower to upper secondary school in Norway. Each of the pupils was interviewed twice: first when they were in their last year of lower secondary education, and then during their first year of upper secondary education. The findings show that pupils consider geographical locations when making decisions about further education and work. In addition, they believe that education beyond compulsory schooling benefits their life in the rural areas. However, unlike their urban counterparts, pupils from rural areas appear to have a more constraining transition to upper secondary education. Through the analyses in this article, it becomes clear that both geographical location and gender are key factors for understanding processes connected to education.
\end{abstract}

Keywords Educational orientation · Decision-making · Pupils · Transition · Structure and agency $\cdot$ Rural-urban youth

Anna-Maria Stenseth

anna-maria.h.stenseth@uit.no

Unn-Doris K. Bæck

unn-doris.k.back@uit.no

1 Department of Education, UiT The Arctic University of Norway, Tromsø, Norway

2 Department of Social Sciences, UiT The Arctic University of Norway, Tromsø, Norway 


\section{Introduction}

Choosing one's education is among the most crucial choices individuals make. It is vital for developing skills and qualifications that will significantly influence the course of one's life. The topic of this article is educational orientations and transitions among young people in Norway and how geographical location plays a part in this regard. As demonstrated by Bæck (2016, 2019), Paulgaard (2017), Lødding and Paulgaard (2019), differences between rural and urban areas can be documented on various educational measures, for example when it comes to test scores, grades and completion rates, from primary school throughout tertiary education (see also Green and Corbett 2013; Nielsen and Faber 2015 on this topic). Even so, and despite a 'spatial turn' within the social sciences at the beginning of the century (see for example Gulson and Symes 2007; Soja 2009), a focus on space has often been lacking in education research, where urban areas have stood out as the norm (for example Beach et al. 2018; Butler and Hamnett 2007; Bæck 2016; Cuervo and Wyn 2012; Farrugia 2014; Hargreaves et al. 2009).

Various factors may influence educational choices and how transitions between different levels of the education system are experienced. Numerous studies have pointed out that gender, parents' educational backgrounds, socioeconomic status (SES) and ethnicity are relevant factors in this regard. Analyses that take other contextual factors into consideration have, however, been rarer. Lent et al. (2000, p. 37) highlight the influence of objective and perceived contextual factors by investigating 'multiple, potentially compensatory aspects of the objective environment' to understand pupils' decisionmaking process. Cuervo and Wyn (2014) emphasise the importance of understanding the relationships between people, places and time for grasping youth transitions. Corbett (2007) has shown how the educational system itself makes it hard for young people to stay in rural areas. In a Nordic context, Waara (1997), Svensson (2006) and Stenseth \& Rød (forthcoming) are among those who have shown that residing in rural areas affects young people's future plans, including the way they think about education.

A number of researchers have also pointed out gender differences when it comes to educational choices among young people residing in rural areas and that rural boys in northern Norway are in an especially vulnerable position regarding education, in the sense that they are underperforming within the education system compared to their urban counterparts and compared to girls (Falch et al. 2010; Markussen 2016; Paulgaard 2017). The aforementioned studies point out several explanations for boys' underperformance, such as insufficient prior knowledge, lack of educational motivation due to the fact that the jobs they aspire for do not demand formal education, with subsequent underperformance and lack of identification with school as a result.

According to Massey (1994, p. 179), spaces and places are gendered and thus reflect and affect ways in which gender is constructed and understood. This is found by Dahlstrom (1996), who in a study from North Norway argues that, while rural girls opted for higher education as a strategy to expand their future options, rural boys were more traditional and less flexible. This leaves the rural males at risk of becoming marginalised (Dahlstrom 1996). Paulgaard (2017) also argues that young males in rural North Norway are victims of economic and structural changes in the labour market and in education and thus at risk of being marginalised. In addition, globalisation puts male identities and relationships 'under the pressure of change and under pressure to change' (Kenway et al. 2006, p. 4). 
Against this background, the analysis in this article pays special attention to the voices of rural boys. The analysis, which draws on data from 33 semi-structured interviews, is based on an investigation of how young people residing in a rural and an urban location in northern Norway reflect around education and how they experience the transition between lower and upper secondary education.

\section{Conceptual Framework}

In order to understand educational orientations and transitions, the interplay between structural factors, individual agency and experiences, encounters with social institutions, how individuals perceive and make sense of opportunities at hand-perceived opportunity structures - and cultural imperatives needs to be taken into consideration. Margaret Archer's analytic framework takes these issues into account by opening for understanding human agency as embedded in structural and cultural properties (2000, 2003, 2007, 2012). Archer's analytic framework therefore serves as an intake to understanding how geographical location affects young people's educational orientations and experiences, and in particular those of rural boys.

In Archer's three-stage model (2007, p. 17), structural and cultural properties objectively shape situations that agents confront involuntarily. These properties possess the generative powers of constraint and enablement in relation to subjects' concerns, which are subjectively defined in relation to the three orders of natural reality: the natural, the practical and the social. Finally, courses of actions are produced through the reflexive deliberations of individuals who determine their projects in relation to context. Archer (2003) argues that, if the powers of constraint and enablement take effect, they must hold in relation to an individual's 'project'. Individuals deliberate whether a project is worth pursuing within their contexts of social placement. To this effect, Archer (2007, p. 7, original italics) states ' $[\mathrm{t}]$ he key point is that any human attempt to pursue a project entails two sets of causal power: our own and those pertaining to part of natural reality'.

According to Archer (2000, pp. 289-290), pupils make their initial choices concerning further education through drawing on their experiences in the natural realm that can be related to play, sports and outdoor activity, which performs a regulatory function over what is sought or shunned when considering the array of occupational roles. Secondly and similarly, pupils review concerns in the practical order that facilitates positive and negative feedback about activities they find satisfactory, such as for instance mending machines. Thirdly, in their social roles, they interrogate the aspects of a role they consider worth having or discarding, which includes inspecting the lifestyles of significant others.

Furthermore, in the last decades, there have been historical changes from what Archer describes as 'contextual continuity', towards an upsurge of 'contextual discontinuity', and recently 'contextual incongruity'. Thus, youths need to prepare for new kinds of opportunities and be ready to move and re-evaluate constellations of concerns (Archer 2012, p. 82). Moreover, Archer links 'contextual continuity to traditional societies' and 'contextual discontinuity' to modernity (2012, p. 82).

Following Archer (2007, p. 17), we understand pupils' concerns and educational projects as defined in relation to constraints and enablements that are subjectively 
defined in relation to the three orders of natural reality. Moreover, the types of knowledge acquired through consulting the three orders are not homogeneous and emerge from different relations between the subject and each order (Archer 2012). As will be shown in the "Results" section, the rural boys are, through reflexive considerations, concerned with dovetailing their project in the practical and the natural order which can explain their sense of attachment to the natal place.

\section{Methods}

This study examines data from $33^{1}$ semi-structured interviews conducted twice with 18 pupils transitioning from the lower to upper secondary school. The pupils were recruited from two lower secondary schools in two municipalities, Coastal Valley ${ }^{2}$ and Tromsø, in Northern Norway. The interviews were conducted using a thematic interview guide, with a focus on relations with friends, family and places; leisure or recreational activities; future plans in terms of education, work and area of residence; and experiences when transitioning to upper secondary education.

\section{Regional Demographics}

Coastal Valley is a small, rural municipality with a declining and ageing population - a demographic trend found in many rural areas in Norway (Leknes et al. 2018). The municipality has less than 3000 inhabitants. Many residents in the municipality are employed in the public health sector, social services or service-related industries. Some work as small-scale farmers and/or fishermen, whereas others commute to the city or oil or construction installations for work. The community centre houses grocery shops, a gas station, local businesses (e.g. car repair shops, hairdressers) and local handicraft. There are occupations in the municipality that demand tertiary education, for instance, a medical centre and several primary and lower secondary schools and kindergartens, as well as the local municipal administration. These occupations can be understood as gendered in the sense that more women work as teachers and nurses (that require tertiary education), while more men are manual workers in local business or commute and work shifts on oil installations or on construction sites (that require upper secondary education).

Tromsø is one of the largest cities in Northern Norway with more than 70,000 inhabitants and an increasing population. The city houses institutions such as a hospital, a county administrative centre, considerable public sector organisations, a university and several upper secondary schools and technical colleges, where people from both Tromsø and (Northern) Norway can study and work.

\section{An Introduction of the Norwegian Education System and the Participants}

In Norway, primary and secondary education is free of cost. Primary and lower secondary education is mandatory. Pupils enrol in the first grade the year they turn 6

\footnotetext{
${ }^{1}$ The material consists of 33 semi-structured interviews with 18 pupils. Four pupils, two in the rural and two in the urban municipality, preferred to do the follow-up interviews in pairs.

${ }^{2}$ Coastal Valley and Grønnvik are fictive names given to protect the anonymity of the places.
} 
and leave the tenth grade the year they turn 16. Approximately $98 \%$ of the pupils continue to upper secondary school where they can choose either a 3 years' academic track or a 3 to 4 years' vocational track (VET). There are five programmes for academic studies and eight vocational education programmes. When completing an academic track, pupils can pursue tertiary education. Women outnumber men in academic study programs, while men dominate in vocational programs (Statistics Norway 2017). In this study, all rural girls, $20 \%$ of rural boys, $40 \%$ of urban girls and $60 \%$ of rural boys attended an academic study program.

Among the urban girls, $60 \%$ attended a VET track, while $80 \%$ of the rural and $40 \%$ of the urban boys did the same.

Generally, VET pupils attend school for 1 to 2 years, followed by 1 to 3 years of onthe-job training to earn an apprenticeship diploma. This track does not qualify for tertiary education; however, pupils have the right to a 1 year's supplementary programme for general university admission after they have achieved vocational competence (with or without a trade or journeyman's certificate).

In this study, $60 \%$ of the rural boys attended the VET program 'Technical and Industrial Program' (TIP) or a similar new program 'Technical and Academic Program' (TAF). The former is a regular program entailing 2 years schooling followed by 1 year of on-the-job training, while the latter is a 4 years' study program that provides pupils with both vocational competence and a university and college admission certification.

The rural case school is multi-graded with less than 100 pupils enrolled in the firsttenth grades. All eight pupils, five boys and three girls, in the 10th grade participated in the study. Participants are given pseudonyms to ensure their anonymity. Regarding grades, there is a spectre from high scoring pupils to pupils with poorer grades.

The urban case school has roughly 400 pupils in the eight-tenth grade. The class teacher helped the researcher select 10 pupils for this study with the aim of ensuring diversity in socioeconomic status (SES), grades and gender. Although there is a greater variety in the urban sample, the rural and urban pupils are comparable concerning grades and to some extent SES. However, slightly more pupils in the rural area have mothers with tertiary education compared to their urban counterparts, whereas more pupils in the urban area have fathers with tertiary education compared to their rural peers.

In this article, the school in Coastal Valley is referred to as the rural school and the one in Tromsø as the urban school. The first round of interviews was conducted in the school building in both schools. The follow-up interviews were conducted when the pupils had completed 3-4 months of upper secondary education. Pupils from the urban area lived at home while attending upper secondary education. All but one pupil from the rural school moved away from home and lived in a bedsitter ${ }^{3}$. For rural pupils, the closest upper secondary school is in a rural municipality, Grønnvik, less than a 2-h bus ride from Coastal Valley. This school offers academic tracks along with several vocational tracks. Most pupils from Coastal Valley attend upper secondary school in Grønnvik while some go to Tromsø, which is more than $2 \mathrm{~h}$ of bus ride from their natal location.

In Grønnvik, pupils can rent a room in a dormitory that has some facilities such as shared bathroom and kitchen and a person who wakes them up in the mornings if they oversleep; however, they need to clean and make their own meals like the pupils renting bedsitters in private homes. Ben is the only pupil from Costal Valley living in a

\footnotetext{
${ }^{3} \mathrm{~A}$ bedsitter is a rented room that generally includes cooking facilities.
} 
dormitory, most rent a room in private homes in Grønnvik, while Cody shares an apartment with other pupils in Tromsø. They pay approximately what they receive in grants (stipend) from the state (ca. 4600 Norwegian kroner) for a bedsitter. In Tromsø, with higher living expenses than Grønnvik, pupils from Coastal Valley rent a bedsitter or share an apartment. When living in bedsitters, pupils rely on their parents for financial support as the grant merely covers housing.

\section{Results}

This section first focuses on the context in which the participants grew up because it serves as a critical backdrop to understanding their educational choices in relation to constraints and enablements. Next, it discusses how the youths oriented themselves towards upper secondary education and their reflections around their transition from lower to upper secondary school.

During the first wave of interviews, the pupils were still living with their parents and were in the process of completing compulsory schooling and applying to upper secondary schools and the next step had gradually become more and more real to them. By March 1st, applications were off for upper secondary education, so important decisions had to be made regarding choice of school and study track for the next 3-4 years.

Participants in this study were raised in geographical contexts that significantly differ from each other in several respects. As shown above, among other things, they differ when it comes to population size and density, industrial structure, centrality and local outbids of education. When asked to describe their everyday lives in the home place, leisure activities were a central part of the informants' descriptions in both places. These activities implied use of local space when e.g. skiing, fishing and biking, but also showed how they related to more supra-local arenas (Bæck 2019), such as gaming, exercising sports or attending the local youth club. The local activities were performed in the youth's home communities, and they were not necessarily easily transferred to other spheres, while supra-local activities were independent of place. As indicated in the "Introduction" section, the rural boys have concerns related to the natural realm (skiing, fishing), which inform their choices when developing life courses (see also Archer 2000, 2012), and their desire to stay in the rural.

The study reveals certain variations in how the youths spent their after-school hours. Pupils from rural areas, especially the boys, interacted with a more diverse group of people in terms of age than their urban counterparts. In addition, the rural boys made greater use of the local environment than the youths from the urban area. These activities require access to local and practical knowledge passed down from older generations. In order to partake in these activities, local knowledge and practical knowhow were of essence, and the boys accessed such knowledge through their interactions across generations. Older men would introduce them to these activities: teach them how to catch fish, show them the locations of the best fishing spots or share knowledge about where it would be safe to go skiing. This indicates that places and spaces are gendered (Massey 1994); the rural girls did not mention partaking in these public activities and, thus, were not interested in or enabled to operate in the natural realm to the same extent as the rural boys. 
Several male pupils from both the rural and urban areas worked after school and during the weekends. While the urban boys worked every other weekend and mainly in stores, the rural boys worked even on weekdays on farms and for small family-owned enterprises. Some of the rural boys talked about how they had given up organised activities so they could dedicate more time to their part-time work: 'We exercised quite a lot [football, ski, taekwondo]. I had time for it all (...) Now, I work quite a lot' (Alan). According to Archer (2000), within the natural and practical spheres, activities can be sought or shunned; in the rural, this appears to be gendered and rural boys seem to enter the 'grown-up world' faster than their peers through local activities, and thus give up more 'youth oriented' activities such as sports and play for work. In current society, shifting from 'contextual continuity' through 'contextual discontinuity' to the upsurge of 'contextual incongruity' (Archer 2012), these rural boys reflexively determine a course of action that enables them to live in the rural, which also includes pursuing secondary (and tertiary) education. They have to pursue education (and work) outside their natal place, which implies having to be flexible. This seemingly aligns their deliberations and actions with Archer's description of 'contextual discontinuity'. However, their desire to stay in the rural is not necessarily an expression of seeking 'contextual continuity' since their reasons for staying are inherently modern as they seek freedom and meaning in the rural, as will be shown below. In addition, they engage with globalisation (Kenway et al. 2006), but resist its association of modernity with urban life by pursuing a life in the rural. According to Kenway et al. (2006, p. 72), young rural males negotiate 'some powerful, conflicting local, state and global forces associated with the world of work and with global ecology'. Furthermore, rural masculinity is associated with work, but the lack of work in many rural places pressures rural males for instance to move or reinvent themselves. In our study, the rural boys pursue education to enable life in the rural even if this means they have to work elsewhere and 'come home' during weekends or when they are off duty in their shift work. As Kenway et al.'s males, 'our' rural boys have to become flexible in order to negotiate 'the world of work'.

\section{Choosing Study Programs}

Shortlisting and applying to schools and programs is a major event, and schools invest considerable effort to ensure their pupils make an informed choice. In 2008, lower secondary Norwegian schools introduced 'Choice of education' (Utdanningsvalg) as an obligatory school subject. The key objectives of the subject are to create coherence between compulsory and upper secondary school and to enhance pupils' career planning competence on the basis of their ambitions and capabilities (Norwegian Directory for Education and Training 2015). The pupils expressed different experiences when it comes to how they felt that teachers, school counsellors or this school subject had assisted them in their decision-making processes. Compared to their urban peers, Coastal Valley's pupils were more content with the subject. They stated that the subject teacher patiently answered their questions and guided them in the right direction, which can also be attributed to the small class size. Urban pupils, however, were given more opportunities to visit schools, universities and a variety of workplaces. Because these latter opportunities are situated in the city, the rural pupils do not have access to them due to economic constraints, which creates inequalities for the rural youths. 
Pupils must choose between an academic and a vocational study program when applying for upper secondary education. In general, many pupils, more girls than boys, apply to an academic study program because they have no specific plans for the future other than pursuing a tertiary education. According to the pupils, this approach was further substantiated by teachers, who would say 'then you can become anything in the future, and you keep your options open'. The lack of clarity also impedes their decision-making processes. One of the rural boys, Cody, was pondering about whether to choose an academic study program, and possibly becoming a teacher. He had not given this a lot of thought though he was far from sure about which occupation he saw for himself. In the follow-up interview, he talked about how his 'internal conversation' went along when choosing upper secondary education:

First, I thought about being open to almost anything. Then, I thought about an academic study program because I didn't know what to choose and what to become. Then, I thought about the places I would stay if I chose to attend school in Grønnvik or Tromsø. In the end, I went for Tromsø because I wouldn't really like attending school in Grønnvik.

Thus, numerous factors influenced Cody's decision including the opportunity to move into Tromsø where he had close relatives. Cody finally opted for an academic study program that also offered more practically oriented subjects and gave him the opportunity to complete his upper secondary education within 3 years. He would also earn a general admissions certificate for his tertiary education, which he planned for. Ben, who also had relatives in the city and had lived there prior to entering primary school, did not consider attending school in Tromsø. His view of city life can be traced in this statement:

[If I were from the city] I would be fonder of shopping and that sort of things... I don't need to buy clothes and stuff. I don't need it. I don't care about travelling. Spending a lot of money going to a place for a week, I couldn't be bothered (Ben).

This could indicate that Ben sought a more 'traditional male' life in the rural and shunned city life, which is discussed in Brandth and Haugen (cf. 2005), stating that rural masculinity is more desirable for males than urban masculinities, which in Ben's view also include shopping and travelling. This notion resonates with Kenway et al. (2006, p. 104) who argue that city spaces, full of girls 'talking and chatting', could be perceived as feminine and thus shunned by some males who find these spaces 'senseless: disruptive, anxiety-provoking cultural mores'.

\section{Vocational Study Programs}

Choosing a vocational study program in upper secondary education implies making a much more specific choice when it comes to future occupation, than an academic study program would do. Choosing a future occupation is difficult for any 15-16-year old, and decisions are often remade and changed later (see also Archer 2000, pp. 289-290). Most of the interviewed boys, both rural and urban as well as one urban girl, who were 
applying for vocational programs knew what kind of work they would like to get intoat least they seemed to have a 'vision' of what to do next.

Odin, from Tromsø, states, '[I have applied for] maritime subjects. I'm going to work on a ship. Firstly, I think I'll do two years as a sailor. Then, I guess I will have further education'. To become a captain on a ship, like his father, Odin would have to complete upper secondary education and then an apprenticeship before pursuing tertiary education. A few other rural male participants expressed the desire to follow in their father's footsteps and accordingly planned their upper secondary education. Alan from Coastal Valley, for example, was certain he would apply for the vocational track, specifically, technical and industrial production (TIP), as early as in the 8th grade: 'I will go to Grønnvik for TIP...Y You can apply for a mechanic program and that sort of things'. For Alan, agriculture lies close to heart since his parents run a farm. He has made an effort to inform himself when it comes to available options, and he takes into consideration future employment at the farm, even though he is aware of the constraints, 'mum and dad don't want me to take over the farm, it's hard to be a smallholder these days'. In their reflexive deliberations, Odin from Tromsø and Alan from Coastal Valley have examined the lifestyles of their parents. Yet, while becoming a captain is within reach for Odin, becoming a smallholder is more constraining for Alan because 'it is hard' in terms of economic profit. Moreover, Alan reflects upon the possibility to start his own firm, but finds it unobtainable because 'you would have to be rich or win the lottery to be able to do so'. Thus, the powers of constraint and enablement take effect in relation to an individual's 'project' (Archer, 2003).

Ben, also from Coastal Valley, is planning to attend the TIP program, primarily because it is practically oriented. As is the case for most of the fathers of the rural boys we interviewed, Ben's father has a practical occupation. He is a plumber who runs his own firm, and even though Ben does not plan on doing the exact same thing as his father, his father seems to be an important role model when it comes to Ben's educational orientations, because Ben aims for manual work like his father. His mother, on the other hand, is a licenced nurse, but Ben does not seem to take her occupation into consideration when he makes his own educational plans. These rural boys might have internalised rural masculine values, such as doing manual work, and view the gains they can receive by reproducing notions of rural, working-class masculinity (Brandth and Haugen 2005) as enabling when seeking a life in the rural. In line with Cuervo and Wyn's (2012, p. 121) rural youth, whose attachment to people and places formed a compelling and enduring point of reference, these rural boys explain their choices based on the opportunities for future occupations in their rural surroundings, which they view as more compatible with attending vocational tracks. This is opposed to Armila et al. (2018) who found that youths' choice of vocational education was not linked to their remote home locations. In addition, Cuervo and Wyn (2012, pp. 126127) argue that educational provision and employment opportunities in cities provide individuals with lots of options, so that the conflicts between where one lives and where one works are minimised. This conflict is present in this study as rural youths perceive restricted occupational opportunities in the rural. In accordance with Armila et al., youths in our study, to some extent, make vocational choices based on parents' experiences. Moreover, the rural youths, in accordance with Cook and Cuervo (2020), do not feel constrained by their rural location, rather they regard returning home as one option selected from a range of choices. 


\section{Uncertainties in Decision-making}

Making educational choices at an early age can be difficult. In fact, some participants changed their minds between the application deadline in March and the outbid of places at the beginning of July. Such uncertainty was particularly present among rural male pupils. Many of them (60\%) applied to an academic study program. Some intended to pursue a tertiary education, while others wanted to keep their options open. The study revealed that certain rural male pupils in the 10th grade intended to apply for an academic track during the initial interview but stated that they had chosen differently as per the follow-up interview. Eric from Coastal Valley explains why he decided to apply to a vocational study program instead of following his initial plan of an academic track:

To start with, I wanted to choose an academic study program because I didn't know what kind of work I wanted to do when it was time to apply. Then I realised that I was so bored [with school].

In the $10^{\text {th }}$ grade, all I learnt felt so wasted because I knew I wouldn't need it. It's the feeling of not doing anything meaningful. I know what they do at TIP. It's mending machines, using tools. It is useful to know and not only for work. I'd rather learn this than things one will never use in the future.

Clearly, Eric was unsure about the type of work he wished to pursue, but he considered tertiary education an option, albeit not a feasible one given the focus on theoretical subjects. Even so, he keeps the scenario open that he may change his mind as he grows older.

Another rural male pupil, David, wanted to combine an academic study program with an athletics program; however, he eventually applied to a vocational study program. David was well informed about the new program, but he had a hard time choosing from the options available:

I didn't want to attend an academic study program, because that meant three years of theoretical subjects. Therefore, I changed to TAF. I now have the opportunity to get a university and college admission certificate. Because I don't want to make that choice already [of further education], I can put it off until next year.

These changes from an academic to vocational tracks could be due to experiences in the natural and practical realms (Archer 2000), where the rural boys sought practical theory offered at VET and occupations known to them as masculine because of watching fathers, relatives and friends performing these roles and shunned occupations regarded as less masculine, like for instance teaching and nursing. These boys are aware that tertiary education can provide 'better' occupational options in the future, but because the powers of constraint and enablement take effect in relation to their 'project' (Archer, 2003), per now these options are postponed, subordinated or abandoned.

Although most pupils did not change their minds regarding study programs, some changed their minds concerning further education. Anja from Coastal Valley wanted to 
become a lawyer in the 10th grade, but had changed her mind because, 'you need good grades...there is so much pressure', and Glenn from Tromsø had reconsidered becoming a dentist 'it is such a boring occupation, I want more action.... Now I've figured that I want to do my education through the army- to become a pilot. I don't see the point in pursuing further education if I can get an education for free in the army'.

\section{Transition to Upper Secondary Education}

The second interview took place after the pupils had attended their new school for some months, and for some of the pupils the transition had been quite notable. They had to familiarise themselves with the new school's rules, schedule, teaching staff and peers.

While all the pupils were unfamiliar with the structure of upper secondary school, the adjustment was far more pronounced among pupils attending VET. VET school included theory subjects taught in standard classroom settings as well as the practical application of theoretical knowledge in the school's garage or kitchen. The first weeks were dedicated to acquainting oneself with peers, teachers and the school, which pupils considered valuable. However, many of VET pupils found that there was little focus on school subjects and that the teachers had low academic expectations to them. They ascribed this approach to the assumption that 'everybody who enrols in VET is tired of school'. The VET pupils found upper secondary school to be far more relevant and interesting than what they had experienced in lower secondary school. The same is found by Mjaavatn and Frostad (2018), who state that pupils became motivated for school and felt more content after entering VET. The pupils enjoyed both the theoretical and practical content, in particular how theoretical subjects were linked with practical application.

The VET pupils also noticed the positive side of being fewer pupils in each class, which meant that the teachers made more time for the individual pupil. The pupils in the academic tracks, on the other hand, felt that the teachers dedicated the same amount of time, or even less time, to each pupil compared to their lower secondary teachers.

\section{Future Plans}

All but one of the pupils who relocated from rural areas intended to return home once they completed their education. However, for some like Eric, this was not necessarily the only route:

When I grow older, I want to settle down in Coastal Valley. In the meantime, I will try to live in different places. I'd like to see how it is to live in a city or abroad. The place where I want to end up is in the valley. As a bachelor, the valley isn't that fun. [I will settle in Coastal Valley] when I find a partner ${ }^{4}$ and want to settle down, maybe at around 30 .

Eric's and also Cody's visions of the future suggest that there are different ways of articulating rural masculinities as they both consider living in different places before

\footnotetext{
$\overline{4}$ The Norwegian term 'kjæreste' is a gender neutral term for girlfriend/boyfriend. The term 'partner' is used here to indicate gender neutrality, although it is not used by the participants.
} 
returning home as well as keeping the choice of tertiary education open. Like David's and Cody's mothers, Eric's mother has a tertiary education, but unlike Svensson's (2006) middle class girls, these rural youths regardless of class (and gender) seem inclined to stay, some after a detour through tertiary education and experimenting different ways of life in the city, as expressed by Charlotte:

I really don't want to move further away from Coastal Valley. It would have been nice to live in the valley when I grow up. If I have children, it would be nice for them to grow up here, because it's nice and safe... I certainly have to pursue further education after upper secondary, but I don't know if there are job opportunities in the valley. So maybe a larger place, cities or something like that.

Charlotte's friend Anja states, 'earlier I didn't want to live in Coastal Valley, but I've reconsidered...I don't think I'll move to Coastal Valley soon. After upper secondary I might go to Tromsø or abroad to study'.

As quoted above, these rural youths do not perceive the rural as a place to leave as the youths in Kåks' (2007) study; however, the girls and a few boys do not consider a fast return. They are also concerned about obtaining employment in the rural as Anja when reflecting upon education, where to settle down and work: 'there isn't a court in Coastal Valley'; thus, it might be convenient to shun pursuing law school, as shown in the section "Uncertainties in Decision-making". As the rural boys, the girls wish to settle in the valley, but contrary to the boys, the rural girls consider tertiary education as the route to employment. They want to stay because the natal place offers safety, freedom and meaning. Furthermore, towards an upsurge of 'contextual discontinuity', and recently 'contextual incongruity', youths need to prepare for new kinds of opportunities and be ready to move and re-evaluate constellations of concerns. The urban youths did not mention negotiating work opportunities in town; however, some of them considered moving to the capital, Oslo or abroad 'to seek better opportunities if being able to continue playing football' (Hans). The rural youths, however, were concerned about the limited opportunities in Coastal Valley. Male rural pupils also mentioned choosing an education program that would help getting work in a rural setting. David, for example, explained: 'Where I would like to live also matters. If I move to [a place further north] next year, then I'll work in shifts [apprenticeship]. Then I can live in Coastal Valley because I'm pretty fond of Coastal Valley'. David explains that he feels freer in Coastal Valley than in the city; in the valley, he can utilise the (well-known) natural realm to a greater extent than in Tromsø. In the 10th grade, David was certain about becoming an engineer, although he soon changed his mind: 'There aren't that many job opportunities in Coastal Valley; for instance, if I were to become an engineer, I couldn't live in the valley'.

\section{Encountering Constraints and Enablements when Relocating}

In Norway, enrolling in upper secondary school can be viewed as a societal expectation, and the youths in this study seem to have internalised this expectation. Bæck (2019)

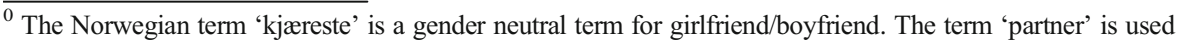
here to indicate gender neutrality, although it is not used by the participants.
} 
suggests that pursuing secondary education is a self-evident aspect of life and the future for a majority of the youths. The present study highlights that selecting a suitable study program and planning future careers are difficult for many. While some changed their minds regarding which track to attend when applying to an upper secondary school, many believed it was too early to make decisions related to their future work. The findings confirm the existence of objective structural and cultural properties that shape the situations pupils confront, whose powers of constraints and/or enablements the pupils negotiate in the three orders of reality (see also Archer 2000, 2007).

The youths in this study are confronted with a situation wherein making educational decisions is a pressing concern. These decisions must be made under any circumstances and sometimes without complete information. Following Archer (2007), when individuals orient themselves in the world, making decisions and choices, they exert their reflexivity as agents. Archer proposes that agents subjectively determine projects in relation to their objective and sociocultural circumstances, and it is these reflexive deliberations that produce courses of action (2007, p. 17). This study focuses on how such decision-making processes are influenced by space. Furthermore, gender relations are significant factors in the structuring of space and place and these relations affect the ways in which gender is understood and constructed in our society (Massey 1994, pp. 182, 186). The relationships between agents and their spatial surroundings are therefore critical in understanding decision-making processes. When making space and place an important aspect of analysis, Archer's structure and agency approach offers fruitful insights into how individuals navigate within structures. Here, spatial emphasis opens up for investigating, e.g. gendered spatial notions (Massey 1994) that point to how spatial factors constrain and/or enable agency.

Archer (2003) maintains that it is easier to feel content if individuals manage to dovetail their concerns with all three orders. However, dovetailing also implies that concerns have to be modified, as well as subordinated and in some cases abandoned (Archer 2012, p. 109). In addition, the prioritisation of concerns is difficult for many youths as they deliberate about further education, careers and relationship as a future part of life. Some rural male pupils are primarily concerned with education programs that will enable them to return home and link their concerns in the natural, physical and social orders. Thus, for instance, David abandons, for the time being, pursuing tertiary education. Female pupils from rural areas do not express location as a key concern in the same way, since their focus lies in obtaining an education that allows them to gain employment in the distant future, as is also the case for the majority of the urban pupils. While the urban youths have a sense of security regarding employment opportunities in the city, the same cannot be said about youths residing in rural areas where the labour market opportunities are less certain. Farrugia (2015) describes how rural youths may reimagine the local through a relation to the outside and how few local options may be constraining. Our study shows that while the urban youths are able to stay, the rural youths must learn how to stay through learning the appropriate skills in their local community and in upper secondary education. They do not reject education, as for example Willis' (1977) classic study of 'the lads' showed. However, as Willis' lads, these boys mainly sought vocational study tracks, even though they first considered an academic track, and their mothers, who have tertiary education, could be important role models in this regard. This could suggest that mastering the rural masculinity norm is sought while more feminine norms are shunned. 
This study highlights that young individuals are active agents and have just begun forming concerns, which, according to Archer, if successful will eventually define who they are. Even though they are involuntarily situated beings, they take action. In the case of male pupils from rural areas, this means gaining an education that will lead them back home. By contrast, most urban youths and female pupils from rural areas delay decisions regarding future work by aspiring for tertiary education. There are some rural boys who consider a detour through tertiary education before settling down in the rural in the future. These actions influence pupils' choice of track. While a majority chooses the academic track, rural male pupils sought a vocational track, even though some initially aspired for the academic track. This could indicate that rural boys seek to dovetail their concerns in the natural and practical realms enabling them to engage in outdoor life and manual work in the rural, even if this means forsaking some initial concerns. Rural male pupils choose education programs and pathways that will enable them to return home (see also Stenseth \& Rød (forthcoming)).

\section{Concluding Remarks}

The findings from the initial and follow-up interviews show that pupils did not necessarily follow their initial plans and changed their minds during the process. Archer (2000) states that internal conversations can be challenging for young people. When confronted with choices, such as that of upper secondary education, pupils tend to draw on previous experiences, including those gained by observing others (Archer 2000, p. 289), like parents and siblings. In other words, 'first choices' are experiments guided by nascent personal identities. Thus, the reasons underpinning a specific choice are based on the pupils' aspired academic or vocational path. It might be the case of the rural boys changing their minds that they sought what could be perceived as rural masculinity, whereas they viewed their mothers' values, including obtaining tertiary education, as feminine and shunned them. However, some rural boys, Eric and Cody, sought a different route that might include tertiary education. Also the rural girls sought an (expected) route through tertiary education that in turn might constrain their wish to return to the rural after completing education because of what they perceive as the lack of desirable job opportunities. These rural youths' routes through the educational system show that there are heterogeneous ways of enacting rural emerging identities.

This study offers a glimpse into internal conversations and decision-making processes among youths in two different contexts (see also Stenseth \& Rød (forthcoming)). Exploring the objective sociocultural circumstances the youths relate to is important in understanding how they define their main concerns. The influence of these circumstances was particularly prevalent among rural pupils whose educational decisions entailed moving away from home at an early age. From Archer's viewpoint, the agential reflexivity the youths demonstrate is actively mediated between structurally shaped circumstances and what is deliberatively made of them (Archer, 2003, p. 130). Therefore, the interplay between sociocultural properties and agential reflexivity is essential when attempting to grasp human actions. This study reveals that contextual factors such as rural/urban settings and future employment opportunities play important roles in pupils' decisions to relocate for pursuing upper secondary education. Some pupils are able to stay, while others learn to stay in their natal community. As this 
study includes few participants, further research including voices from participants in various locations could give an even more thorough explanation of how structural and cultural constraints and enablements affect youths' agency.

Acknowledgements We wish to thank Professor Halla Holmarsdottir, Anna Loppacher, Daniel Rød and two anonymous reviewers for their constructive comments.

Declarations On behalf of all authors, the corresponding author states that there is no conflict of interest. The study was approved by NSD - Norwegian Centre for Research Data, and was performed in accordance with the ethical standards as laid down in the 1964 Declaration of Helsinki and its later amendments or comparable ethical standards.

All the participants have agreed to the study and signed an informed consent. Since the participants were 1516 years old during the first phase of interviews, parents were also informed and able to withdraw their youths from of the study.

Funding This work was supported by Norges Forskningsråd grant number 255444/H20. Open access funding provided by UiT The Arctic University of Norway (incl University Hospital of North Norway).

Open Access This article is licensed under a Creative Commons Attribution 4.0 International License, which permits use, sharing, adaptation, distribution and reproduction in any medium or format, as long as you give appropriate credit to the original author(s) and the source, provide a link to the Creative Commons licence, and indicate if changes were made. The images or other third party material in this article are included in the article's Creative Commons licence, unless indicated otherwise in a credit line to the material. If material is not included in the article's Creative Commons licence and your intended use is not permitted by statutory regulation or exceeds the permitted use, you will need to obtain permission directly from the copyright holder. To view a copy of this licence, visit http://creativecommons.org/licenses/by/4.0/.

\section{References}

Archer, M. S. (2000). Being human: the problem of agency. Cambridge University Press, Cambridge

Archer MS (2003) Structure, agency and the internal conversation. Cambridge University Press, Cambridge Archer MS (2007) Making our way through the world: human reflexivity and social mobility. Cambridge University Press, Cambridge

Archer, M. S. (2012). The reflexive imperative in late modernity: Cambridge University Press.

Armila P, Käyhkö M, Pöysä V (2018) On the educational edges of a learning society: the Finnish hinterland as a framework of educational choices for young people. J Youth Stud 21(9):1198-1215. https://doi.org/10. 1080/13676261.2018.1453128

Bæck U-DK (2016) Rural location and academic success-remarks on research, contextualisation and methodology. Scand J Educ Res 60(4):435-448. https://doi.org/10.1080/00313831.2015.1024163

Bæck U-DK (2019) Spatial manoeuvring in education: educational experiences and local opportunity structures among rural youth in Norway. Nordic Journal of Comparative and International Education (NJCIE) 3(3):61-74. https://doi.org/10.7577/njcie.3274

Beach D, From T, Johansson M, Öhrn E (2018) Educational and spatial justice in rural and urban areas in three Nordic countries: a meta-ethnographic analysis. Educ Inq 9(1):4-21. https://doi.org/10.1080/20004508. 2018.1430423

Brandth B, Haugen MS (2005) Doing rural masculinity-from logging to outfield tourism. J Gend Stud 14(1): 13-22. https://doi.org/10.1080/0958923042000331452

Butler T, Hamnett C (2007) The geography of education: introduction. Urban Stud 44(7):1161-1174

Cook J, Cuervo H (2020) Staying, leaving and returning: rurality and the development of reflexivity and motility. Curr Sociol 68(1):60-76. https://doi.org/10.1177/0011392118756473

Corbett M (2007) Learning to leave: the irony of schooling in a coastal community. Fernwood Publ, Halifax 
Cuervo, H., \& Wyn, J. (2012). Young people making it work: continuity and change in rural places: Melbourne University Press, Melbourne.

Cuervo H, Wyn J (2014) Reflections on the use of spatial and relational metaphors in youth studies. J Youth Stud 17(7):901-915. https://doi.org/10.1080/13676261.2013.878796

Dahlstrom M (1996) Young women in a male periphery: experiences from the Scandinavian North. J Rural Stud 12(3):259-271. https://doi.org/10.1016/0743-0167(96)00018-6

Falch, T., Borge, L.-E., Lujala, P., Nyhus, O. H., \& Strøm, B. (2010). Årsaker til og konsekvenser av manglende fullføring av videregående opplæring.

Farrugia D (2014) Towards a spatialised youth sociology: the rural and the urban in times of change. J Youth Stud 17(3):293-307. https://doi.org/10.1080/13676261.2013.830700

Farrugia D (2015) Addressing the problem of reflexivity in theories of reflexive modernisation: subjectivity and structural contradiction. J Sociol 51(4):872-886. https://doi.org/10.1177/1440783313480396

Green, B., \& Corbett, M. (2013). Rural education and literacies: an introduction. In Rethinking Rural Literacies (pp. 1-13): Springer.

Gulson KN, Symes C (2007) Knowing one's place: space, theory, education. Critical Studies in Education 48(1):97-110. https://doi.org/10.1080/17508480601123750

Hargreaves L, Kvalsund R, Galton M (2009) Reviews of research on rural schools and their communities in British and Nordic countries: analytical perspectives and cultural meaning. Int J Educ Res 48:80-88. https://doi.org/10.1016/j.ijer.2009.02.001

Kåks, H. (2007). Mellan erfarenhet och förväntan: Betydelser av att bli vuxen i ungdomars livsberättelser. Dissertation. Linköping University Electronic Press, Linköping.

Kenway, J., Kraack, A., \& Hickey-Moody, A. (2006). Masculinity beyond the metropolis. London: London: Palgrave Macmillan UK.

Leknes, S., Løkken, S. A., Syse , A., \& Tønnessen, M. (2018). Befolkningsframskrivingene 2018. Modeller, forutsetninger og resultater [Norway's 2018 population projections. Models, conditions and results]. Retrieved from Oslo: http://hdl.handle.net/11250/2558090

Lent RW, Brown SD, Hackett G (2000) Contextual supports and barriers to career choice: a social cognitive analysis. J Couns Psychol 47(1):36-49

Lødding B, Paulgaard G (2019) Spørsmål om tid og sted: Mulighetsrom og kvalifiseringsbaner blant ungdom utenfor videregående opplæring i Finnmark. https://doi.org/10.7577/njcie.3273

Markussen E (2016) De' hær e'kke nokka for mæ. In: Rogstad J, Reegård K (eds) De Frafalne: Om frafall $i$ videregående opplaring - hvem er de, hva vil de og hva kan gjøres? Gyldendal akademiske, Oslo

Massey, D. (1994). Space, place, and gender. University of Minnesota Press, Minneapolis

Mjaavatn PE, Frostad P (2018) Fra ungdomsskole til videregående skole - hvordan opplever elevene overgangen? Norsk pedagogisk tidsskrift (3):282-297. https://doi.org/10.18261/issn.1504-2987-201803-07

Nielsen HP, Faber ST (2015) Remapping gender, place and mobility: global confluences and local particularities in Nordic peripheries. Ashgate, Farnham

Norwegian Directory for Education and Training. (2015). Lareplan for utdanningsvalg på ungdomstrinnet [The curriculum for Choice of education in lower secondary school]. (UTV1- 02). Retrieved from https:// www.udir.no/k106/UTV1-02

Paulgaard G (2012) Geography of opportunity: approaching adulthood at the margins of the northern European periphery. In: Bæck UDK, Paulgaard G (eds) Rural futures? Finding one's place within changing labour markets. Orkana Akademisk, Stamsund, Norway, pp 189-215

Paulgaard G (2017) Geographies of inequalities in an area of opportunities: ambiguous experiences among young men in the Norwegian High North. Geogr Res 55(1):38-46. https://doi.org/10.1111/1745-5871.12198

Soja E (2009) The city and spatial justice. Justice spatiale/Spatial justice 1(1):1-5

Statistics Norway. (2017). 90 per cent male pupils on some programmes. Retrieved from https://www.ssb.no/ en/utdanning/artikler-og-publikasjoner/90-per-cent-male-pupils-on- some-programmes

Stenseth AM, Rød DAV (forthcoming) Reflexivity and educational decision-making processes among young pupils. In: Archer MS, Bæck U-DK, Skinningsrud T (eds.) The morphogenesis of the Norwegian educational system: Emergence and Development. London, Routledge

Svensson L (2006) Vinna och försvinna?: Drivkrafter bakom ungdomars utflyttning från mindre orter. Linköping University Electronic Press, Linöping, Dissertation

Waara PM (1997) Ungdom i gransland. Boréa Bokförlag, Umeå, Sweden

Willis PE (1977) Learning to labour: how working class kids get working class jobs. Saxon House, Farnborough 